\title{
Effect of Supplementation With Selenium-Yeast on Muscle Antioxidant Activity, Meat Quality, Fatty Acids and Amino Acids in Goats
}

OPEN ACCESS

Edited by:

Dan Wan,

Chinese Academy of Sciences

(CAS), China

Reviewed by:

Pramote Paengkoum,

Suranaree University of

Technology, Thailand

Duanqin Wu,

Chinese Academy of Agricultural

Sciences (CAAS), China

*Correspondence:

Qi LU

luqi2556728@163.com

Xiang Chen

xchen2@gzu.edu.cn

Specialty section:

This article was submitted to Animal Nutrition and Metabolism,

a section of the journal

Frontiers in Veterinary Science

Received: 12 November 2021 Accepted: 28 December 2021

Published: 25 January 2022

Citation:

Tian X-Z, Li J-X, Luo Q-Y, Wang X, Xiao $M-M$, Zhou D, LU $Q$ and Chen $X$ (2022) Effect of Supplementation With Selenium-Yeast on Muscle Antioxidant Activity, Meat Quality, Fatty Acids and Amino Acids in Goats.

Front. Vet. Sci. 8:813672. doi: 10.3389/fvets.2021.813672

\author{
Xing-Zhou Tian ${ }^{1}$, Jia-Xuan Li ${ }^{1}$, Qing-Yuan Luo ${ }^{1}$, Xu Wang ${ }^{1}$, Mei-Mei Xiao ${ }^{1}$, Di Zhou ${ }^{2}$, \\ Qi Lu ${ }^{1 *}$ and Xiang Chen ${ }^{1 *}$
}

${ }^{1}$ Key Laboratory of Animal Genetics, Breeding and Reproduction in the Plateau Mountainous Region, Ministry of Education, College of Animal Science, Guizhou University, Guiyang, China, ${ }^{2}$ Testing Center for Livestock and Poultry Germplasm, Guizhou Agricultural and Rural Affairs Office, Guiyang, China

The objective of this study was to observe the effects of selenium-yeast (SY) on growth performance, muscle antioxidant activity, meat quality, fatty acid and amino acid profiles in growing goats. A total of 18 Qianbei-pockmarked goats were assigned to three groups (six duplicates per group) by body weight $(25.75 \pm 1.75 \mathrm{~kg}$; mean \pm standard deviation) according to a completely randomized design: (1) basal diet (CON); (2) CON with 2.4 $\mathrm{mg} / \mathrm{kg}$ SY (LS); and (3) CON with $4.8 \mathrm{mg} / \mathrm{kg}$ SY (HS). The results indicated that goats receiving $S Y$ did not show any differences $(P>0.05)$ in terms of dry matter intake, growth performance, or muscle chemical composition. In addition, dietary treatment did not affect $(P>0.05)$ the $\mathrm{pH}$ values $\left(\mathrm{pH}_{45 \text { min }}\right.$ and $\left.\mathrm{pH}_{24 h}\right)$, percentage of water loss, drip loss, or cooking loss. The HS group showed a significant increase $(P<0.05)$ in the dressing percentage, eye muscle area and meat color, as well as muscle total antioxidant capacity, glutathione peroxidase and 2,2-diphenyl-1-picrylhydrazyl scavenging activity levels, whereas it showed a significant drop $(P<0.05)$ in shear force and muscle malondialdehyde levels relative to the control. Feeding $4.8 \mathrm{mg} / \mathrm{kg} S Y$ led to a significant $(P<0.05)$ decrease in the levels of C8:0, C14:0, C15:0, C16:0, C17:0, C18:0, C20:0 and total saturated fatty acids, whereas it led to a significant $(P<0.05)$ increase in $\mathrm{C} 15: 1$ in comparison with that of the control group. Goats receiving $2.4 \mathrm{mg} / \mathrm{kg} S Y$ had significantly $(P<0.05)$ increased C16:1, C17:1, C18:1n7, C18:2n6, C18:3n3, C20:4n6, C22:1n9, and PUFA relative to the control group. Compared with the control group, the treatment groups had higher $(P<0.05)$ levels of $C 18: 1 n 9, C 22: 4$, and monounsaturated fatty acids. The inclusion of $2.4 \mathrm{mg} / \mathrm{kg}$ SY induced significant $(P<0.05)$ increases in 4-aminobutyric acid, glutamic acid and umami amino acid concentrations compared to the control. In addition, the feeding of $4.8 \mathrm{mg} / \mathrm{kg}$ SY had significantly higher $(P<0.05)$ muscle serine, valine, isoleucine, leucine, ornithine hydrochloride, methionine, and tyrosine levels than the control group. Collectively, Se supplementation in the diet did not affect growth performance, muscle chemical composition, whereas it could improve meat quality, muscle antioxidant activity, fatty acid and amino acid profiles in Qianbei-pockmarked goats. This showed that the optimal accession SY level was $4.8 \mathrm{mg} / \mathrm{kg}$ under the experimental conditions of this study.

Keywords: selenium-yeast, antioxidant activity, meat quality, fatty acid, amino acid 


\section{INTRODUCTION}

When the body suffers from oxidative stress (OS), the amount of reactive oxygen species (ROS) is enhanced and the antioxidant capacity decreases, leading to the initiation of lipid peroxidation, which may cause DNA oxidative damage and abnormal protein expression (1). The development of antioxidants to alleviate OS is popular with many researchers (2). The most important and known biological effect of selenium (Se) is its antioxidative effect. Indeed, $\mathrm{Se}$ is an essential trace element that has many biological functions, especially in preventing lung cancer, carcinoma of the prostate and liver cancer. However, excessive or inadequate Se intake will lead to physiological disorders or diseases. Se deficiency or excess can lead to poisoning caused by gastrointestinal disorders, vomiting, nausea, and diarrhea, thereby leading to impaired physiological functions (3).

Supplementation of Se in ruminant feed is achieved with additives such as sodium selenite, sodium selenate and seleniumyeast (SY) Saccharomyces cerevisiae. Antunović et al. (4) showed that organic Se in the feed could be transferred to the muscle and organs, and organic Se had a better bioavailability than inorganic Se in fattening lambs. Notably, SY is a source of organic Se (mainly selenomethionine) because it can be absorbed and retained more readily than inorganic Se (5). The general requirement for Se in the diet of ruminants is $0.1-0.3 \mathrm{mg} / \mathrm{kg}$, and the maximum tolerance of Se is $5 \mathrm{mg} / \mathrm{kg}$ (6). Vignola et al. (7) demonstrated that lambs receiving low levels ( 0.30 and 0.45 $\mathrm{mg} / \mathrm{kg} \mathrm{SY}$ ) of SY had no differences in growth performance, feedto-gain ratio, carcass or meat quality. Goats generally have a strong tolerance of Se, and SY at a high level $(4.0 \mathrm{mg} / \mathrm{kg})$ is a relatively safe Se supplement for goats (6).

Polyunsaturated fatty acids (PUFAs) are important for body health. However, ruminant products have been criticized for their saturated fatty acids (SFAs) may have adverse effects on human health, which has contributed to declining consumption (8). Se has been proven to have strong antioxidant activity, delaying the onset of muscle oxidation reactions (9). Hence, ruminant receiving SY had the ability to improve unsaturated fatty acid (UFA) profiles in ruminant products. Moreover, Se has the capability of preventing apoptosis initiated by ROS and it participates in the regulation of amino acid (AA) profiles (10). Therefore, adding Se to the goat diet can not only improve growth performance but also enhance immune responses and antioxidant activity (11). However, research on the influence of a high dose of SY on meat quality in goats is rather limited. Considering the above, we hypothesized that a high dietary dose of SY would increase longissimus dorsi (LD) muscle antioxidant activity, improving meat quality, muscle fatty acids (FAs) and AAs derived from goats. Accordingly, the current research was performed to observe whether supplementation with Se in the diet could affect the meat quality, muscle antioxidant activity, FA and AA of Qianbei-pockmarked goats.

\section{MATERIALS AND METHODS}

\section{Animals, Diets, and Experimental Design}

The feeding trial was carried out at a commercial goat farm (Guizhou, China). Signs of Se toxicity usually start to appear at
TABLE 1 | Ingredients and nutrient composition of experimental diets (DM basis).

\begin{tabular}{|c|c|c|c|}
\hline Ingredients, \% & Content & Chemical composition, \% & Content \\
\hline Peanut vines & 50.00 & Dry matter & 90.15 \\
\hline White distiller's grains & 10.00 & Crude protein & 11.95 \\
\hline Soybean residues & 10.00 & Gross energy, kJ/g & 16.33 \\
\hline Green hay & 9.30 & Neutral detergent fiber & 42.74 \\
\hline Corn & 16.00 & Acid detergent fiber & 28.61 \\
\hline Soybean meal & 3.00 & Ether extract & 2.35 \\
\hline Mineral premixa & 0.50 & Ash & 8.72 \\
\hline Vitamin premix ${ }^{b}$ & 0.50 & Calcium & 0.96 \\
\hline $\mathrm{NaCl}$ & 0.50 & Phosphorus & 0.15 \\
\hline Limestone & 0.20 & & \\
\hline Total & 100.00 & & \\
\hline
\end{tabular}

a Vitamin premix was purchased Guangzhou Everrich Animal Health Co., Ltd. (Guangzhou, China), and contained the following vitamins per kilogram feed: $4000000 \mathrm{IU}$ of vitamin A, $600000 \mathrm{IU}$ of vitamin D, 25,000 mg of vitamin E, 7,000 mg of DL-methionine, and $5,000 \mathrm{mg}$ of L-lysine.

${ }^{b}$ Mineral premix was obtained the Earth Animal Nutrition and Health Products Co., Ltd. (Chongqing, China), and contained the following minerals per kilogram feed: 1,300 mg of $\mathrm{Cu}, 1,000 \mathrm{mg}$ of $\mathrm{Fe}, 1,575 \mathrm{mg}$ of $\mathrm{Zn}$, and $595 \mathrm{mg}$ of $\mathrm{Mn}$.

Se levels of $5-8 \mathrm{mg} / \mathrm{kg} \mathrm{DM}$ in ruminants (12). Therefore, the goats were raised for $74 \mathrm{~d}$, which included a preparation period of $14 \mathrm{~d}$ and a formal experimental period of $60 \mathrm{~d}$. Eighteen Qianbei-pockmarked wether goats (a Guizhou native goat breed) were assigned to three groups (six duplicates per group) by body weight (BW, $25.75 \pm 1.75 \mathrm{~kg}$; mean \pm standard deviation) according to a completely randomized design: (1) basal diet (CON); (2) CON with $2.4 \mathrm{mg} / \mathrm{kg}$ SY (LS); and (3) CON with $4.8 \mathrm{mg} / \mathrm{kg}$ SY (HS). The SY as part of the basal ration and was mixed in the concentrate, and then the concentrate was mixed with the roughage evenly. SY was obtained from Jiangsu Qianbo Bioengineering Co., Ltd., Jiangsu, China. The information of SY is: food additive production license No. SC20133062401397, the Se content of the SY is $2000 \mathrm{ppm}$, and the appearance is a yellow powder with a uniform fineness. During the experiment, all animals received water freely and were fed at 08:30 and 16:30 for ad libitum intake. The rations were made according to the National Research Council [(13); NRC, Table 1].

\section{Chemical Composition}

Approximately $100 \mathrm{~g}$ of base diet was collected once weekly and mixed after the end of the feeding trial, and $500 \mathrm{~g}$ of feed was collected and dried at $65^{\circ} \mathrm{C}$ in a vacuum oven for $72 \mathrm{~h}$, ground and passed through a 1-mm sieve for further analysis. The chemical composition of dry matter (DM), crude protein $(\mathrm{CP})$, ether extract (EE), ash, calcium (Ca), phosphorus $(\mathrm{P})$ and gross energy (GE) were measured according to the Association of Official Analytical Chemists [(14); AOAC]. Neutral detergent fiber (NDF) and acid detergent fiber (ADF) were determined according to Van Soest et al. (15). Each sample was analyzed in triplicate.

\section{Growth Performance}

Dry matter intake (DMI) was recorded as the intake of each group of goats every day, and BW was measured on the first day 
and the last day before the morning feeding to calculate the initial weight (IW) and final weight (FW). The following formulas were used to calculate the average net gain (ANG), average daily gain (ADG), and feed conversion ratio (FCR): ANG $(\mathrm{kg})=\mathrm{FW}(\mathrm{kg})$ - IW $(\mathrm{kg}) ; \mathrm{ADG}(\mathrm{g} / \mathrm{d})=\mathrm{ANG} / 74 \times 1000 ; \mathrm{FCR}=\mathrm{DMI} / \mathrm{ADG}$ $\times 100 \%$.

\section{Antioxidant Activity}

The LD homogenate was prepared as follows: chopped tissue and phosphate buffered saline (PBS) were added to the glass homogenizer (1:9), and the homogenate was broken by ultrasonication using a Bransonic ${ }^{\circledR}$ ultrasonic cleaner (Branson ultrasonics corporation, USA). Next, the supernatant was transferred to a $1.5 \mathrm{~mL}$ tube after centrifugation at $4,000 \times \mathrm{g}$ for $10 \mathrm{~min}$ at $4^{\circ} \mathrm{C}$ and stored at $-80^{\circ} \mathrm{C}$ until further analysis. The total antioxidant capacity (TAC), superoxide dismutase (SOD), glutathione peroxidase (GSH-Px), catalase (CAT), and malondialdehyde (MDA) were detected by using commercial assay kits (Nanjing Jiangcheng Bioengineering Institute, Nanjing, China) according to the operation guide of the kit. The 2,2diphenyl-1-picrylhydrazyl (DPPH) scavenging activity was noted according to our previous study (16).

\section{Meat Quality}

Six goats per group were slaughtered at the end of the experiment for carcass and the left LD muscle was separated for meat quality examination. The parameters as follows: (1) live weight before slaughter $(\mathrm{kg})$ : the body weight was measured after stopping feeding for $24 \mathrm{~h}$ and water for $2 \mathrm{~h}$ before slaughter; (2) carcass weight $(\mathrm{kg})$ : after slaughter, blood, fur, head, hoof, and internal organs (the kidney and kidney fat were retained) were removed, weighing the carcass after standing for 20-30 min; (3) dressing percentage (\%): dressing percentage $=$ (carcass weight/live weight before slaughter) $\times 100$; (4) eye muscle area $\left(\mathrm{cm}^{2}\right)$ : the cross-sectional area of the LD muscle between the $12^{\text {th }}$ and $13^{\text {th }}$ ribs of the carcass, the outline of the cross section of the eye muscle was drawn with sulfuric acid drawing paper, and then the eye muscle area was calculated by using a digital planimeter KP-90N (No. H18049, made in Japan); (5) pH: the pH value was detected by a pH-star (Matthäus, Eckelsheim, Germany); (6) percentage of water loss (\%): a $1 \mathrm{~cm}$ thick sample was cut with a $2.5 \mathrm{~cm}$ diameter and weighed, then the sample was pressed under $35 \mathrm{~kg}$ for $5 \mathrm{~min}$ and weighed again, and the percentage of water loss $=[$ (prepressure weight - postpressure weight $) /$ prepressure weight] $\times 100$; (7) drip loss (\%): the trimmed meat sample $(2.0$ $\times 3.0 \times 5.0 \mathrm{~cm})$ was put in a special plastic bag, the bag was inflated and closed, then it was placed in a $4^{\circ} \mathrm{C}$ refrigerator for $24 \mathrm{~h}$, the juice on the surface of the meat sample was wiped off with filter paper, and the meat was weighed, drip loss $=[$ (initial weight-final weight)/initial weight] $\times 100 \%$; (8) cooking loss (\%): $\sim 100 \mathrm{~g}$ of sample $\left(\mathrm{m}_{1}\right)$ was weighed after removing the fascia, epimysium or fat, and the sample was boiled in water for $30 \mathrm{~min}$, cooled for $30 \mathrm{~min}$ and weighed $\left(\mathrm{m}_{2}\right)$, cooking loss $=\left(\mathrm{m}_{1}-\mathrm{m}_{2}\right)$ $\times 100$; (9) shear force $(\mathrm{kg})$ : shear force was observed by a digital display tenderness meter (Xielikeji Co., Ltd., Harbin, China) after drilling the muscle column along the direction of the muscle fiber; and (10) meat color (Opto): meat color was measured using an Opto-Star equipment (Company MATTHÄUS, KLAUSA). Each sample was tested in triplicate.

\section{Fatty Acids}

FAs were extracted using a chloroform methanol solution according to Tian et al. (17). Individual FAs were detected using a gas chromatography mass spectrometer (GC-MS; Thermo Fisher Scientific, USA). The GC-MS conditions were as follows: Thermo TG-FAME capillary column $(50 \mathrm{~m} \times 0.25 \mathrm{~mm}$ $\times 0.20 \mu \mathrm{m}), 1 \mu \mathrm{L}$ of injection volume, split ratio of $8: 1$; injection port temperature of $250^{\circ} \mathrm{C}$, ionization temperature of $230^{\circ} \mathrm{C}$, transmission line temperature of $250^{\circ} \mathrm{C}$, and quadrupole temperature of $150^{\circ} \mathrm{C}$. Helium gas was used as the carrier, the flow rate of the carrier gas was $0.63 \mathrm{~mL} / \mathrm{min}$, and the energy of ionization was $70 \mathrm{eV}$.

\section{Amino Acids}

A total $50 \mathrm{mg}$ of meat sample was weighed and transferred to a $2 \mathrm{~mL}$ tube. Then, $600 \mu \mathrm{L}$ of $10 \%$ formic acid methanol solution and two steel balls were added and it was run at $60 \mathrm{~Hz}$ for $1 \mathrm{~min}$ using a high-throughput tissue grinder. Ten microliters of supernatant was added to $490 \mu \mathrm{L}$ of $10 \%$ formic acid methanol solution after centrifugation at $12,000 \times \mathrm{g}$ for $5 \mathrm{~min}$ at $4^{\circ} \mathrm{C}$ (Hunan Xiangyi Centrifuge Instrument Co., Ltd., H1850R, Hunan, China) and vortexed at $30 \mathrm{~s}$ by a vortex mixer (Haimen Kylin-bell Lab Instruments Co., Ltd., QL866, Jiangsu, China). The $100 \mu \mathrm{L}$ of diluted sample was mixed with $100 \mu \mathrm{L}$ of dual isotope internal standard (100 ppb) and vortexed at $30 \mathrm{~s}$. The sample was filtered through a $0.22 \mu \mathrm{m}$ nylon syringe filter, and the amino acids were detected with a Waters ACQUITY ultraperformance liquid chromatography (UPLC, Waters, Milford, USA) system and tandem mass spectrometry (MS, SCIEX6500Qtrap; AB Allen-Bradley, Milwaukee, WI) using the internal standard method.

The UPLC conditions were as follows: individual AAs were separated on an ACQUITY UPLC ${ }^{\circledR}$ BEH C18 column (2.1 $\times 100 \mathrm{~mm} \times 1.7 \mu \mathrm{m}$, Waters, Milford, USA) with a column temperature of $40^{\circ} \mathrm{C}$; the injection volume was $5 \mu \mathrm{L}$; mobile phase: $\mathrm{A}=10 \%$ methanol (containing $0.1 \%$ formic acid) and $\mathrm{B}=50 \%$ methanol (containing $0.1 \%$ formic acid). The gradient elution conditions were as follows: $0 \sim 6.5 \mathrm{~min}, 10 \sim 30 \%$ B; $6.5 \sim 7 \mathrm{~min}, 30 \sim 100 \% \mathrm{~B} ; 7 \sim 8 \mathrm{~min}, 100 \% \mathrm{~B} ; 8 \sim 8.5 \mathrm{~min}$, $10 \sim 100 \% \mathrm{~B} ; 8.5 \sim 12.5 \mathrm{~min}, 10 \% \mathrm{~B}$. The flow rate was as follows: $0 \sim 8.5 \mathrm{~min}, 0.3 \mathrm{~mL} / \mathrm{min} ; 8.5 \sim 12.5 \mathrm{~min}, 0.3 \sim 0.4 \mathrm{~mL} / \mathrm{min}$. The MS conditions were as follows: electrospray ionization source, positive ion ionization mode; ion power temperature was $500^{\circ} \mathrm{C}$, ion source voltage was $5,500 \mathrm{~V}$; collision gas pressure of 6 psi, curtain gas pressure of 30 psi; nebulization gas pressure and aux gas pressure were both $50 \mathrm{psi}$; and multiple-reaction monitoring scan mode. Twenty-two amino acids were detected: alanine (Ala), 4-aminobutyric acid (GABA), serine (Ser), glycine (Gly), proline (Pro), valine (Val), threonine ( $\mathrm{Thr}$ ), isoleucine (Ile), leucine (Leu), asparagine (Asn), ornithine hydrochloride (Orn), aspartic acid (Asp), homocysteine (Hcy), glutamine (Gln), lysine (Lys), glutamic acid (Glu), methionine (Met), histidine (His), phenylalanine (Phe), arginine (Arg), tyrosine (Tyr), and tryptophan (Trp). 
TABLE 2 | Effect of purple corn pigment on DMl and growth performance of goats.

\begin{tabular}{lccccc}
\hline Item $^{1}$ & \multicolumn{3}{c}{ Group $^{2}$} & SEM & P-value \\
\cline { 2 - 4 } & Control & LS & HS & & \\
\hline DMl, g/d & 816.26 & 810.22 & 814.33 & 6.7455 & 0.8113 \\
Initial weight, kg & 25.45 & 25.80 & 26.01 & 0.6431 & 0.8231 \\
Final weight, kg & 29.80 & 30.16 & 30.88 & 0.6136 & 0.4875 \\
ANG, kg & 4.35 & 4.36 & 4.36 & 0.1692 & 0.9993 \\
ADG, g & 72.56 & 72.72 & 72.70 & 2.8176 & 0.9990 \\
FCR & 11.32 & 11.32 & 11.32 & 0.4567 & 0.9999 \\
\hline
\end{tabular}

${ }^{1}$ Values represent the mean of six replicates $(n=6)$.

${ }^{2} D M l$, dry matter intake; ANG, average net gain; ADG, average daily gain; FCR, feed conversion ratio.

TABLE 3 | Effect of selenium-yeast on muscle antioxidant activity and immune of goats $^{1}$.

\begin{tabular}{lccccc}
\hline Item $^{2}$ & \multicolumn{3}{c}{ Group $^{3}$} & SEM & P-value \\
\cline { 2 - 4 } & Control & LS & HS & \\
\hline TAC, U/mL & $4.56^{\mathrm{b}}$ & $7.36^{\mathrm{ab}}$ & $9.87^{\mathrm{a}}$ & 1.0668 & 0.0348 \\
SOD, U/mL & 22.46 & 22.54 & 22.89 & 0.2868 & 0.5594 \\
GSH-Px, U/mL & $170.02^{\mathrm{b}}$ & $204.14^{\mathrm{ab}}$ & $238.27^{\mathrm{a}}$ & 14.9544 & 0.0489 \\
CAT, U/mL & 19.27 & 19.16 & 19.10 & 0.0562 & 0.2514 \\
MDA, nmol/mL & $4.37^{\mathrm{a}}$ & $1.84^{\mathrm{b}}$ & $1.28^{\mathrm{b}}$ & 0.5888 & 0.0047 \\
DPPH scavenging activity, \% & $7.36^{\mathrm{b}}$ & $14.50^{\mathrm{a}}$ & $14.20^{\mathrm{a}}$ & 1.1177 & 0.0312 \\
& & & & &
\end{tabular}

${ }^{1 a-b}$ Different letters within a row are significantly different $(P<0.05)$.

${ }^{2}$ Values represent the mean of six replicates $(n=6)$.

${ }^{3}$ TAC, total antioxidant capacity; SOD, superoxide dismutase; GSH-PX, glutathione peroxidase; CAT, catalase; MDA, malondialdehyde; DPPH, 2,2-diphenyl-1-picrylhydrazyl.

TABLE 4 | Effect of selenium-yeast on muscle chemical composition of goats.

\begin{tabular}{lccccc}
\hline Item $^{1}$ & \multicolumn{3}{c}{ Group } & SEM & P-value \\
\cline { 2 - 4 } & Control & LS & HS & & \\
\hline Moisture, \% & 73.71 & 73.90 & 73.07 & 0.6206 & 0.6343 \\
Gross energy, kJ/g & 22.39 & 22.59 & 22.76 & 0.2635 & 0.6371 \\
Crude protein,\% & 80.97 & 81.90 & 80.38 & 0.9186 & 0.5131 \\
Ether extract, \% & 8.87 & 8.22 & 8.67 & 0.9032 & 0.8755 \\
Ash, \% & 5.99 & 6.22 & 5.84 & 0.4716 & 0.8653 \\
Calcium, \% & 0.33 & 0.32 & 0.37 & 0.0381 & 0.7202 \\
Phosphorus, \% & 0.16 & 0.18 & 0.18 & 0.0403 & 0.9435 \\
\hline
\end{tabular}

${ }^{1}$ Values represent the mean of six replicates $(n=6)$.

\section{Statistical Analysis}

The observations were analyzed by using the Statistical Analysis System 9.1.3 software (SAS Institute, Cary, NC, USA) to conduct a one-way analysis of variance model: $Y_{i j}=\mu+\tau_{i}+\varepsilon_{i j}$, where $Y_{i j}$ is the observation $j(j=1-6)$ in the treatment $i(i=C O N, L S$, and HS), $\mu$ is the overall mean, $\tau_{i}$ is the effect of the treatment, $\varepsilon_{i j}$ is the random error with a mean of 0 and variance $\sigma^{2}$. The level of significance was set to 0.05 .
TABLE 5 | Effect of selenium-yeast on carcass traits of goats ${ }^{1}$.

\begin{tabular}{|c|c|c|c|c|c|}
\hline \multirow[t]{2}{*}{ Item $^{2}$} & \multicolumn{3}{|c|}{ Group } & \multirow[t]{2}{*}{ SEM } & \multirow[t]{2}{*}{$P$-value } \\
\hline & Control & LS & HS & & \\
\hline Live weight before slaughter, kg & 25.60 & 24.11 & 26.57 & 0.7146 & 0.1245 \\
\hline Carcass weight, kg & 11.23 & 10.48 & 12.30 & 0.5345 & 0.1304 \\
\hline Dressing percentage, \% & $43.88^{b}$ & $43.48^{b}$ & $46.23^{a}$ & 0.4943 & 0.0156 \\
\hline Eye muscle area, $\mathrm{cm}^{2}$ & $12.31^{b}$ & $11.67^{\mathrm{b}}$ & $13.99^{a}$ & 0.5118 & 0.0109 \\
\hline $\mathrm{pH}_{45 \min }$ & 6.03 & 6.20 & 5.78 & 0.1331 & 0.2338 \\
\hline $\mathrm{pH}_{24 \mathrm{~h}}$ & 5.19 & 5.40 & 5.08 & 0.2572 & 0.6741 \\
\hline Percentage of water loss, \% & 3.22 & 3.50 & 3.96 & 0.3894 & 0.4262 \\
\hline Drip loss, \% & 1.10 & 1.44 & 0.94 & 0.2418 & 0.3543 \\
\hline Cooking loss, \% & 71.96 & 71.15 & 66.41 & 1.9499 & 0.1285 \\
\hline Shear force, kg & $5.42^{\mathrm{a}}$ & $4.96^{b}$ & $4.29^{\mathrm{c}}$ & 0.1520 & 0.0004 \\
\hline Meat color, Opto & $69.07^{\mathrm{b}}$ & $70.62^{\mathrm{ab}}$ & $74.63^{a}$ & 1.7376 & 0.0972 \\
\hline
\end{tabular}

${ }^{1 a-c}$ Different letters within a row are significantly different $(P<0.05)$.

${ }^{2}$ Values represent the mean of six replicates $(n=6)$.

\section{RESULTS}

\section{Growth Performance}

Adding SY had no significant influence $(P>0.05)$ on the DMI, growth performance (ANG, ADG) or the FCR of the goats (Table 2).

\section{Antioxidant Activity}

The inclusion of HS resulted in significantly higher $(P<0.05)$ levels of muscle TAC, GSH-Px and DPPH scavenging activity than that of the control group (Table 3). In contrast, goats receiving HS exhibited a significant decline $(P<0.05)$ in MDA concentration compared with the control group.

\section{Meat Quality}

As shown in Table 4, the muscle chemical composition was not influenced significantly $(P>0.05)$ by dietary SY supplementation. Similarly, there was no difference $(P>0.05)$ in live weight before slaughter or carcass weight among the dietary treatment groups (Table 5). However, the dressing percentage of goats fed a high SY diet was higher $(P<0.05)$ than that of goats fed a basal or low SY diet. Furthermore, adding a high dosage of SY significantly increased $(P<0.05)$ the eye muscle area of the goats. The lowest shear force was presented by goats fed HS, followed by LS and the control $(P<0.05)$. Dietary treatment did not affect $(P>0.05)$ the $\mathrm{pH}$ values $\left(\mathrm{pH}_{45 \min }\right.$ and $\left.\mathrm{pH}_{24 \mathrm{~h}}\right)$, percentage of water loss, drip loss, or cooking loss. Meat color from the goats in the HS group was significantly $(P<0.05)$ darker than that in the other groups.

\section{Fatty Acids}

For the SFA profiles, muscle C11:0 and C21:0 were not detected in either of the two treatments (Table 6). Feeding $4.8 \mathrm{mg} / \mathrm{kg} \mathrm{SY}$ led to significantly $(P<0.05)$ decreased levels of C8:0, C14:0, C15:0, C16:0, C17:0, C18:0, C20:0 and total SFAs compared with the control group. For the UFA profiles, goats receiving $2.4 \mathrm{mg} / \mathrm{kg}$ 
TABLE 6 | Effect of selenium-yeast on longissimus dorsi fatty acid of goats ${ }^{1}$.

\begin{tabular}{|c|c|c|c|c|c|}
\hline \multirow{2}{*}{$\begin{array}{l}\text { Items }^{2}, \mu \mathrm{g} / \mathrm{g} \text { fresh } \\
\text { muscle }\end{array}$} & \multicolumn{3}{|c|}{ Group $^{3}$} & \multirow[t]{2}{*}{ SEM } & \multirow[t]{2}{*}{$P$-value } \\
\hline & Control & LS & HS & & \\
\hline SFA profiles & 1.563 & 1.243 & 1.225 & 0.2053 & 0.5075 \\
\hline \multicolumn{6}{|l|}{ C6:0 } \\
\hline C8:0 & $2.459^{a}$ & $1.218^{b}$ & $1.138^{b}$ & 0.2425 & 0.0515 \\
\hline C10:0 & 5.603 & 6.656 & 6.423 & 0.6689 & 0.5697 \\
\hline C11:0 & 0.907 & ND & ND & - & - \\
\hline C12:0 & 3.159 & 3.253 & 2.373 & 0.6081 & 0.5903 \\
\hline C13:0 & 3.031 & 2.668 & 2.170 & 0.3273 & 0.3143 \\
\hline C14:0 & $239.286^{a}$ & $88.203^{b}$ & $42.475^{\mathrm{C}}$ & 14.3397 & 0.0047 \\
\hline C15:0 & $20.798^{a}$ & $19.151^{a b}$ & $16.585^{\mathrm{b}}$ & 0.6038 & 0.0356 \\
\hline C16:0 & $1336.799^{a}$ & $1227.075^{a}$ & $949.880^{b}$ & 52.5783 & 0.0290 \\
\hline C17:0 & $54.791^{\mathrm{a}}$ & $38.120^{\mathrm{ab}}$ & $33.478^{b}$ & 3.7999 & 0.0564 \\
\hline C18:0 & $1153.294^{a}$ & $1046.130^{a b}$ & $824.310^{b}$ & 58.8402 & 0.0615 \\
\hline C2O:0 & $10.090^{\mathrm{a}}$ & $9.362^{\mathrm{ab}}$ & $7.549^{b}$ & 0.5499 & 0.0959 \\
\hline $\mathrm{C} 21: 0$ & 1.841 & ND & ND & - & - \\
\hline $\mathrm{C} 22: 0$ & 1.199 & 1.111 & 1.025 & 0.0782 & 0.4067 \\
\hline C24:0 & 0.860 & 0.556 & 0.551 & 0.0991 & 0.1804 \\
\hline SFA & $2832.932^{a}$ & $2444.745^{a}$ & $1889.183^{b}$ & 96.8306 & 0.0143 \\
\hline \multicolumn{6}{|l|}{ UFA profiles } \\
\hline C14:1 & 12.233 & 12.769 & 12.408 & 0.8436 & 0.9033 \\
\hline C15:1 & $3.164^{b}$ & $3.765^{\mathrm{ab}}$ & $4.251^{a}$ & 0.1156 & 0.0159 \\
\hline C16:1 & $33.416^{c}$ & $74.780^{\mathrm{a}}$ & $60.249^{b}$ & 1.2307 & 0.0004 \\
\hline C17:1 & $11.880^{b}$ & $26.373^{a}$ & $18.840^{\mathrm{ab}}$ & 1.6770 & 0.0203 \\
\hline C18:1n7 & $45.507^{b}$ & $79.469^{a}$ & $52.032^{b}$ & 2.3755 & 0.004 \\
\hline C18:1n9 & $643.434^{b}$ & $1053.533^{a}$ & $1199.596^{a}$ & 36.9793 & 0.0037 \\
\hline C18:1n12 & 629.701 & 672.080 & 691.810 & 73.6957 & 0.8396 \\
\hline C18:2n6 & $160.463^{b}$ & $239.745^{a}$ & $164.527^{b}$ & 10.2805 & 0.0200 \\
\hline C18:3n3 & $8.375^{b}$ & $16.063^{a}$ & $10.766^{a b}$ & 1.5727 & 0.0850 \\
\hline C2O:1 & 9.409 & 10.515 & 6.790 & 0.9903 & 0.1535 \\
\hline C20:2 & 3.811 & 3.889 & 2.490 & 0.5603 & 0.2842 \\
\hline C20:3n6 & 15.489 & 15.539 & 12.191 & 1.5585 & 0.3508 \\
\hline C20:4n6 & $193.545^{b}$ & $242.500^{a}$ & $201.060^{\mathrm{ab}}$ & 9.4848 & 0.0656 \\
\hline C20:5n3 & 6.399 & 8.519 & 6.880 & 0.8689 & 0.3308 \\
\hline C22:1n9 & $67.442^{b}$ & $84.764^{a}$ & $66.917^{b}$ & 2.4024 & 0.0215 \\
\hline $\mathrm{C} 22: 4$ & $22.019^{b}$ & $28.588^{a}$ & $28.423^{a}$ & 0.7843 & 0.0153 \\
\hline C22:5n3 & 28.127 & 31.578 & 28.668 & 1.1157 & 0.2084 \\
\hline C22:5n6 & 5.571 & 4.996 & 4.982 & 0.2241 & 0.2531 \\
\hline C22:6n3 & 4.662 & 4.171 & 4.819 & 0.7170 & 0.8129 \\
\hline C24:1 & 13.752 & 12.300 & 11.358 & 11.358 & 0.2210 \\
\hline MUFA & $1469.939^{b}$ & $2030.351^{a}$ & $2124.252^{a}$ & 47.4271 & 0.0043 \\
\hline PUFA & $448.460^{\mathrm{b}}$ & $595.589^{a}$ & $464.807^{b}$ & 9.9248 & 0.0033 \\
\hline
\end{tabular}

${ }_{1 a-c}$ Different letters within a row are significantly different $(P<0.05)$.

${ }^{2}$ Values represent the mean of six replicates $(n=6)$.

${ }^{3} N D$, not detected; SFA, sum of all the saturated fatty acid; MUFA, sum of all the monounsaturated fatty acid; PUFA, sum of all the polyunsaturated fatty acid.

SY had significantly $(P<0.05)$ increased C16:1, C17:1, C18:1n7, $\mathrm{C} 18: 2 \mathrm{n} 6, \mathrm{C} 18: 3 \mathrm{n} 3, \mathrm{C} 20: 4 \mathrm{n} 6, \mathrm{C} 22: 1 \mathrm{n} 9$, and PUFA relative to the control group. In addition, supplementation with a high dose of SY $(4.8 \mathrm{mg} / \mathrm{kg})$ led to a significant $(P<0.05)$ increase in
TABLE 7 | Effect of selenium-yeast on longissimus dorsi amino acid of goats ${ }^{1}$.

\begin{tabular}{|c|c|c|c|c|c|}
\hline \multirow[t]{2}{*}{ Item $^{2}, \mu \mathrm{g} / \mathrm{g}$ fresh muscle } & \multicolumn{3}{|c|}{ Group $^{3}$} & \multirow[t]{2}{*}{ SEM } & \multirow[t]{2}{*}{$P$-value } \\
\hline & Control & LS & HS & & \\
\hline Ala & 499.99 & 476.86 & 535.56 & 13.3912 & 0.1141 \\
\hline GABA & $2.97^{\mathrm{b}}$ & $6.33^{\mathrm{a}}$ & $1.51^{b}$ & 0.5517 & 0.0183 \\
\hline Ser & $128.68^{b}$ & $144.50^{\mathrm{ab}}$ & $153.42^{\mathrm{a}}$ & 4.0041 & 0.0484 \\
\hline Gly & ND & ND & ND & - & - \\
\hline Pro & 33.86 & 37.72 & 37.68 & 5.1362 & 0.8386 \\
\hline Val & $63.35^{\mathrm{b}}$ & $54.94^{b}$ & $84.91^{\mathrm{a}}$ & 4.2188 & 0.0319 \\
\hline Thr & 38.44 & 39.49 & 46.95 & 3.6363 & 0.3319 \\
\hline lle & $24.59^{b}$ & $23.84^{\mathrm{b}}$ & $42.56^{a}$ & 3.6072 & 0.0569 \\
\hline Leu & $59.89^{b}$ & $52.26^{b}$ & $78.13^{\mathrm{a}}$ & 3.4790 & 0.0285 \\
\hline Asn & 607.13 & 590.97 & 646.23 & 33.8619 & 0.5615 \\
\hline Orn & $13.09^{b}$ & $23.72^{\mathrm{ab}}$ & $31.95^{\mathrm{a}}$ & 2.7746 & 0.0387 \\
\hline Asp & $27.55^{\mathrm{ab}}$ & $38.00^{\mathrm{a}}$ & $14.64^{b}$ & 3.5104 & 0.0410 \\
\hline Hcy & ND & ND & ND & - & - \\
\hline Gln & $2105.77^{\mathrm{ab}}$ & $2464.45^{a}$ & $2029.24^{b}$ & 83.5823 & 0.0655 \\
\hline Lys & 137.13 & 121.46 & 121.08 & 13.0921 & 0.6546 \\
\hline Glu & $127.67^{b}$ & $240.74^{a}$ & $94.34^{b}$ & 19.4901 & 0.0262 \\
\hline Met & $22.69^{b}$ & $21.50^{\mathrm{b}}$ & $32.07^{a}$ & 1.8712 & 0.0499 \\
\hline His & 656.24 & 476.20 & 690.34 & 107.5521 & 0.4272 \\
\hline Phe & $30.06^{\mathrm{ab}}$ & $25.91^{b}$ & $40.75^{a}$ & 2.5850 & 0.0558 \\
\hline Arg & 91.38 & 87.72 & 78.34 & 5.0183 & 0.3072 \\
\hline Tyr & $43.68^{b}$ & $36.64^{b}$ & $72.02^{\mathrm{a}}$ & 3.5099 & 0.0112 \\
\hline Trp & 8.09 & 7.74 & 12.05 & 1.1869 & 0.1398 \\
\hline TAA & 4722.26 & 4970.99 & 4843.77 & 173.0152 & 0.6414 \\
\hline EAA & 384.25 & 347.14 & 458.49 & 29.3495 & 0.1535 \\
\hline UAA & $728.95^{\mathrm{b}}$ & $818.15^{a}$ & $757.32^{\mathrm{ab}}$ & 15.5887 & 0.0477 \\
\hline
\end{tabular}

${ }^{1 a-b}$ Different letters within a row are significantly different $(P<0.05)$.

${ }^{2}$ Values represent the mean of six replicates $(n=6)$.

${ }^{3} N D$, not detected; Ala, alanine; GABA, 4-aminobutyric acid; Ser, serine; Gly, glycine; Pro, proline; Val, valine; Thr, threonine; Ile, isoleucine; Leu, leucine; Asn, asparagine; Orn, ornithine hydrochloride; Asp, aspartic acid; Hcy, homocysteine; Gln, glutamine; Lys, lysine; Glu, glutamic acid; Met, methionine; His, histidine; Phe, phenylalanine; Arg, arginine; Tyr. tyrosine; Trp, tryptophan; TAA, total amino acid; EAA, essential amino acid (Val, Thr, lle, Leu, Lys, Met, Phe, Trp); UAA, umami amino acid (Gly, Ala, Asp, Glu, Phe, Tyr).

C15:1 in comparison with that of the control group. Compared to the control group, there were higher $(P<0.05)$ levels of $\mathrm{C} 18: \ln 9, \mathrm{C} 22: 4$, and monounsaturated FAs (MUFAs) in the treatment groups.

\section{Amino Acids}

As shown in Table 7, there were no significant differences $(P>$ 0.05) in muscle Ala, Pro, Thr, Asn, Lys, His, Arg, Trp, total AA (TAA), or essential AA (EAA) values among the three groups. Moreover, Gly and Hcy were unable to be detected in all groups. Compared to the control, feeding with $2.4 \mathrm{mg} / \mathrm{kg} \mathrm{SY}$ induced significant $(P<0.05)$ increases in GABA, Glu and umami amino acid (UAA) concentrations. Furthermore, the HS group had significantly higher $(P<0.05)$ muscle Ser, Val, Ile, Leu, Orn, Met, and Tyr levels than the control group. 


\section{DISCUSSION}

Small ruminants are more prone to OS status, resulting in reduced growth performance and impaired immunity, leading to depressed husbandry efficiency (18). Hence, finding a suitable method to improve the antioxidation ability of small ruminants and eliminate free radicals (FRs) is a hot subject. Se is not produced by the body and must be obtained through food and water (19). Dietary Se supplementation is the most common method to improve the Se status of ruminants. Se is an essential trace element in biological life activities, playing a biological function in the form of selenoproteins, such as GSH$\mathrm{Px}$, thioredoxin reductases, deiodinases, and selenoproteins; alternatively, Se exerts its biological function when incorporated into proteins as selenocysteine residues, replacing the sulfur moiety in cysteine (20). Thus, Se, as a component of inactivators of toxic heavy metals, plays an important structural and enzymatic function, able to neutralize ROS and enhance antioxidant activity, protecting against lipid oxidation in the ruminant body (21). Indeed, Se can improve the antioxidant defense system in the body by modulating ROS-generating enzymes and additional synthesis of antioxidant enzymes and promoting inflammation in a cooperative and interactive way, being critically important for the ruminant's adaptation to nutritional stress (22).

Chauhan et al. (23) reported that Se supplementation could improve antioxidant enzymes in the body, protecting against OS and improving ruminant health. Vignola et al. (7) showed that supplementation with Se can enhance muscle Se levels, reducing the lipid oxidation of lambs. Thus, adding SY to the diet could strengthen antioxidant activity in muscle in this study, perhaps because Se is a part of the active center of GSH-Px, which can catalyze the reduction of peroxides (24). This may also be attributed to dioxide Se being a source of oxidant, which can oxidize some groups, such as hydroxides and methyl groups, to aldehyde groups and is reduced to Se itself during the chemical reaction (25). Consistent with our conclusions, Alimohamady et al. (26) showed that dietary Se supplementation did not impact the DMI, ADG, and FCR, whereas it can improve GSH-Px activity in lambs. Similar values of antioxidant activity in the body of fattening lambs receiving Se were obtained by Antunović et al. (4).

Meat quality traits include color, texture, hardness, tenderness, marble, etc. Among them, the amount of fat deposition and depositional mode are very important. The dressing percentage is an important index to evaluate carcass quality. Generally, the larger the eye muscle area is, the higher the lean meat rate (27). Netto et al. (28) showed that Se supplementation altered lipid metabolism in confined Brangus cattle by reducing the cholesterol concentration in the meat. Similarly, Se intake led to altered mRNA expression of genes associated with cholesterol and lipid metabolism parameters in the liver and LD muscle of growing Polish Merino lambs (29). In the current study, the addition of high SY to the diet improved the dressing percentage and eye muscle area, which may be related to Se regulating fat deposition by regulating lipid metabolism parameters in ruminants. Tenderness is critically important from a sensory viewpoint. Shear force is a measurement that indicates tenderness, mechanically assessed through the force necessary to sever the muscle fibers (30). Meat tenderness is among the important determinants of sensory quality parameters associated with consumer preferences. In the present study, goat meat from the SY diet had a lower shear force value than that from the control diet, indicating a tender texture. Meat is primarily comprised of myoglobin $(\mathrm{Mb})$. The $\mathrm{O}_{2}$ molecule can be bound to $\mathrm{Fe}^{2+}$ and is stabilized through hydrogen binding by the nearby distal His (31). Hence, an important reason for the meat color changing is because the $\mathrm{Fe}^{2+}$ in $\mathrm{Mb}$ is unstable, and it is easy to oxidize to $\mathrm{Fe}^{3+}$, resulting in discoloration of the product (32). Therefore, supplementation with SY could improve the meat color of goats, suggesting that Se may prevent the oxidation of $\mathrm{Fe}^{2+}$ to $\mathrm{Fe}^{3+}$, thus improving the meat color.

It is well-known that $\mathrm{O}_{2}$ is vital for all animals. However, some $\mathrm{O}_{2}$ is converted to superoxide $\left(\mathrm{O}_{2}^{-}\right)$and then converted into hydrogen peroxide $\left(\mathrm{H}_{2} \mathrm{O}_{2}\right)$ and $\mathrm{H}_{2} \mathrm{O}$ by SOD, GSH-Px, and CAT enzymes $(33,34)$. FR scavengers are substances that can scavenge FR or block FR involved in oxidative reactions. Additionally, most FR scavengers are antioxidants, which can control the formation of FR by reducing the concentration of active FR intermediates and reducing the efficiency of the expansion stage in the FR chain reaction. UFAs in lipids are active in chemical activities because they contain multiple double bonds, very susceptible to destruction by FR and peroxidation (35). Lipid peroxidation in UFAs is a reaction where FR removes an electron from the lipids because molecular $\mathrm{O}_{2}$ is incorporated into unsaturated lipids to form a lipid hydroperoxide (36). Hence, lipid peroxidation is a natural phenomenon involved in peroxidative loss of unsaturated lipids, thus causing lipid degradation and membrane disorders (37). Ruminant meat is characterized by a high SFA content and a low PUFA content due to biohydrogenation of UFAs in the rumen by microflora (38). Purba et al. (39) did show that SFAs are showed in higher levels compared to the PUFAs in ruminant meat. In biological systems, lipid peroxidation is controlled by antioxidant defense systems that include antioxidant nutrients. Although Se is not an antioxidant, it is necessary for the production of several enzymes that affect the antioxidant network. Additionally, Se exists in the cytoplasm and mitochondrial matrix, which can reduce toxic peroxides to non-toxic hydroxyl compounds and decompose $\mathrm{H}_{2} \mathrm{O}_{2}$ into alcohols and water (40). Noticeably, Se also has a synergistic effect with vitamin $\mathrm{E}$, which means that the two nutrients are more powerful than either one alone (19). Kišidayová et al. (41) demonstrated that SY could impact the intake of dietary PUFAs by rumen microbes, especially rumen ciliates, as well as the biohydrogenation of PUFAs to more SFAs. Niedwiedzka et al. (42) suggested that feeding SY can improve the muscle MUFA and PUFA ratios and increase the concentration of EAAs. Thus, Se has a strong antioxidant function, which can improve the content of beneficial FAs in animal byproducts by regulating the hydrogenation of PUFAs in the rumen.

Low intake and poor utilization of feedstuffs could be negative effect on the rumen ecosystem and rumen fermentation (43, 44). Adding of SY did not differ on the DMI and growth performance, while it could improve antioxidant activity in 
goat meat. Moreover, Ferreira et al. (45) who showed that Se supplementation did not improve rumen fermentation and nutrient utilization, but it tended to increase the concentration of PUFA in omasum flow of FAs. Thus, we observed that SY could improve the meat UFA concentrations of goats in the present study. The mechanism may be related to increasing the antioxidant activity and inhibiting the production of FR, resulting in a reduction in the lipid peroxidation reaction. In addition, feed composition affects ruminal fluid fermentation $(46,47)$, the affinity of rumen microorganisms (48). Dietary supplementation of SY may improve UFA concentrations by altering rumen fermentation model and ruminal microbiota in goats. Further studies are needed to observe the effect of SY on ruminal microorganisms. This is consistent with the results of Aghwan et al. (49), who demonstrated that supplementation with Se can lead to an increase in UFAs in the supraspinatus, longissimus lumborum, and semitendinosus muscles in Kacang goats. Yong et al. (50) also had a similar observation, that Korean native Hanwoo cattle fed a diet supplemented with organic Se had improved growth performance, carcass traits, and meat quality with an enriched PUFA profile. However, Pereira et al. (51) found that Nellore steers receiving Se did not have any changes in the FA profile of their $L D$ muscle. The reason for the different observations may be as follows: (1) adding different SYs as the source of Se to the daily diet; (2) different species of animals have different metabolic pathways of Se; and (3) different Se compounds and their structural formulas could also be contributing factors $(52,53)$.

When the body is in a state of OS, it may participate in the AA metabolic process because ROS can also oxidize blood and structural proteins and inhibit the proteolytic system (54). Dai et al. (55) showed that cysteine limitation reduces the biosynthesis of glutathione (GSH) and causes the depletion of GSH, which directly inhibits the activity and stability of GPX4. In addition, cystathionine, cysteine and glycine are important precursors in the synthesis of GSH-Px, which has a rate-limiting role in the synthesis process (56). Indeed, AA has been shown to regulate the upstream glutathione synthesis pathway by reducing OS and the subsequent inflammatory response in ruminants (57). Specifically, most of the Se in the body exists in the active center of specific selenoproteins/selenases in the form of selenocysteine, is non-specifically incorporated into ordinary proteins in the form of selenomethionine, and it exists in the form of methylated Se compounds (58). In this study, Se cleared the FR in goats and upregulated the OS status of the body, thereby improving muscle AAs. Additionally, protein oxidation can cause AA loss or they can be fragmented, leading to alterations of structural proteins or alterations of enzyme functions (54). This is perhaps because Se in the liquid phase binds to protein, followed by microbial cell protein hydrolysis, and then it is absorbed as a Secontaining free AA (59). Of interest, the AA content increased with supplementation with a high dose of SY in this study. One possible reason is that ruminal bacteria are capable of utilizing Se from selenite and selenate for the synthesis of selenoamino acids (60). For young ruminants, Se is closely linked with vitamin E and sulfur-containing AAs (61). Gressley (62) who found that Se is covalently bound to AA to form AA complex trace minerals, with increased bioavailability in ruminants, suggested that allows more AA to be deposited in muscle. This might also be the reason for the lower apparent Se absorption by ruminants than by monogastric animals.

The types of AA can be divided into tasteless, bitter, sweet, and umami amino acid according to taste characteristics. The UAAs are represented by Gly, Ala, Asp, Glu, Phe, and Tyr. When the expression of umami substance regulatory genes is high, the content of umami substances in the meat is also increased (63). In addition, adenylosuccinate lyase (ADSL) plays a key role in the formation of umami substances. Interestingly, muscle tenderness can be affected by cellular antioxidants, and ADSL has been previously identified as a putative biomarker of tenderness, being positively correlated with beef tenderness (64). In the current study, SY improved UAA in the LD muscle of goats. Regarding the possible mechanism, it could be assumed that Se can prevent excessive FR, enhance antioxidant enzymes and modulate ADSL-related umami gene expression in the body, thus leading to an increase in UAA content in the muscle of goats, but this needs further verification. Additionally, the meat is rich in Se concentration, the integrity of cell membrane is protected after slaughter, reducing the loss of umami substances, and thus improving UAA content in LD muscle in goats. In short, the experimental results demonstrated that SY supplementation may be useful for growing goats because of its high antioxidant potential.

\section{CONCLUSION}

The findings of the current study suggest that dietary Se supplementation could not only improve the muscle antioxidant activity and meat quality but also improve the amino acid and fatty acid profiles of meat from Qianbei-pockmarked goats. Additional studies are required to clarify the effects of SY on the conjugated PUFA concentrations in the rumen microorganisms of goats from transcriptomics and metagenomics.

\section{DATA AVAILABILITY STATEMENT}

The raw data supporting the conclusions of this article will be made available by the authors, without undue reservation.

\section{ETHICS STATEMENT}

The animal study was reviewed and approved by the Experimental Animal Ethics, Guizhou University (Guiyang, China).

\section{AUTHOR CONTRIBUTIONS}

X-ZT: data curation, writing-original draft preparation, investigation, and data curation. J-XL, Q-YL, XW, and MMX: investigation and data curation. DZ: supervision. QL: methodology and writing-reviewing and editing. XC: project administration and supervision. All authors have read and approved the final manuscript. 


\section{FUNDING}

The research was funded by the Science and Technology Project of Guizhou Province (Qiankehe foundation-ZK[2021] General 164), the National Natural Science Foundation

\section{REFERENCES}

1. Valko M, Rhodes CJ, Moncol J, Izakovic M, Mazur M. Free radicals, metals and antioxidants in oxidative stress-induced cancer. Chem Biol Interact. (2006) 160:1-40. doi: 10.1016/j.cbi.2005.12.009

2. Purba RAP, Paengkoum P. Bioanalytical HPLC method of Piper betle L for quantifying phenolic compound, water-soluble vitamin, and essential oil in five different solvent extracts. J Appl Pharm Sci. (2019) 9:0339. doi: 10.7324/JAPS.2019.90504

3. Zarczyńska K, Sobiech P, Radwińska J, Rekawek W. Effects of selenium on animal health. J Elementol. (2013) 18:329-40. doi: 10.5601/jelem.2013.18.2.12

4. Antunović Z, Novoselec J, Klapec T, Cavar S, Mioč B, Šperanda M. Influence of different selenium sources on performance, blood and meat selenium content of fattening lambs. Ital J Anim Sci. (2009) 8:1635. doi: 10.4081/ijas.2009.s3.163

5. Sevcikova L, Pechova A, Pavlata L, Antos D, Mala E, Palenik T, et al. The effect of various forms of selenium supplied to pregnant goats on the levels of selenium in the body of their kids at the time of weaning. Biol Trace Elem Res. (2011) 143:882-92. doi: 10.1007/s12011-010-8884-x

6. Shi L, Ren Y, Zhang C, Yue W, Lei F. Effects of organic selenium (se-enriched yeast) supplementation in gestation diet on antioxidant status, hormone profile and haemato-biochemical parameters in Taihang black goats. Anim Feed Sci Tech. (2018) 238:57-65. doi: 10.1016/j.anifeedsci.2018.02.004

7. Vignola G, Lambertini L, Mazzone G, Giammarco M, Tassinari M, Martelli $\mathrm{G}$, et al. Effects of selenium source and level of supplementation on the performance and meat quality of lambs. Meat Sci. (2009) 81:67885. doi: 10.1016/j.meatsci.2008.11.009

8. Dewhurst RJ, Scollan ND, Lee MRF, Ougham HJ, Humphreys MO. Forage breeding and management to increase the beneficial fatty acid content of ruminant products. Proc Nutr Soc. (2003) 62:329-36. doi: 10.1079/PNS2003241

9. Juniper DT, Phipps RH, Ramosmorales E, Bertin G. Effect of dietary supplementation with selenium-enriched yeast or sodium selenite on selenium tissue distribution and meat quality in beef cattle. J Anim Sci. (2008) 86:3100-9. doi: 10.2527/jas.2007-0595

10. Abdelnour SA, El-Hack MEA, Khafaga AF, Arif M, Taha AE, Noreldin AE. Stress biomarkers and proteomics alteration to thermal stress in ruminants: a review. J Therm Biol. (2019) 79:120-34. doi: 10.1016/j.jtherbio.2018.12.013

11. Aditia M, Sunarso S, Sevilla CC, Angeles AA. Growth performance and mineral status on goats (Caprahircuslinn.) supplemented with zinc proteinate and selenium yeast. Sci Res Essays. (2014) 7:1741-51. doi: 10.12777/ijse.7.2.124-129

12. Arshad MA, Ebeid HM, Hassan F. Revisiting the effects of different dietary sources of selenium on the health and performance of dairy animals: a review. Biol Trace Elem Res. (2021) 199:3319-37. doi: 10.1007/s12011-020-02480-6

13. National Research Council. Nutrient Requirements of Goats: Angora, Dairy, and Meat Goats in Temperate and Tropical Countries. Washington, DC; The National Academies Press (1981).

14. Association of Official Analytical Chemists. Association of Official Analytical Chemists Official Methods of Analysis. 18th ed. Washington, DC; AOAC (2005).

15. Van Soest PV, Robertson JB, Lewis BA. Methods for dietary fiber, neutral detergent fiber, and nonstarch polysaccharides in relation to animal nutrition. J Dairy Sci. (1991) 74:3583-97. doi: 10.3168/jds.S0022-0302(91)78551-2

16. Tian XZ, Li JX, Luo QY, Zhou D, Long QM, Wang X, et al. Effects of purple corn anthocyanin on blood biochemical indexes, ruminal fluid fermentation, and rumen microbiota in goats. Front Vet Sci. (2021) 8:715710. doi: $10.3389 /$ fvets.2021.715710 of China (31760652), the Cultivating Project of Guizhou University (2019-33), the Start-up Fund of Guizhou University (2016-76; 2019-26), and the Core Program of Science and Technology Department of Guizhou Province (QKH[2019]2279), respectively.

17. Tian XZ, Lu Q, Paengkoum P, Paengkoum S. Short communication: effect of purple corn pigment on change of anthocyanin composition and unsaturated fatty acids during milk storage. J Dairy Sci. (2020) 103:780812. doi: 10.3168/jds.2020-18409

18. Tian XZ, Paengkoum P, Paengkoum S, Thongpea S, Ban C. Comparison of forage yield, silage fermentative quality, anthocyanin stability, antioxidant activity, and in vitro rumen fermentation of anthocyanin-rich purple corn (Zea mays L.) stover and sticky corn stover. J Integr Agr. (2018) 17:208295. doi: 10.1016/S2095-3119(18)61970-7

19. Packer L, Colman C. The Antioxidant Miracle. Syracuse, NY; John Wiley and Sons, Inc (2000).

20. Chauhan SS, Celi P, Ponnampalam EN, Leury BJ, Liu F, Dunshea FR. Antioxidant dynamics in the live animal and implications for ruminant health and product (meat/milk) quality: role of vitamin E and selenium. Anim Prod Sci. (2014) 54:1525-36. doi: 10.1071/AN14334

21. Kruzhel B, Bakowska M, Vovk S, Nowakowska E, Sergei P. Selenium in the diet of ruminants. Acta Sci Pol Zootechnica. (2014) 13:5-16. Available online at: https://asp.zut.edu.pl//2014/13_4/asp-2014-13-4-256.pdf

22. Surai PF, Kochish II, Fisinin VI, Juniper DT. Revisiting oxidative stress and the use of organic selenium in dairy cow nutrition. Animals. (2019) 9:462. doi: 10.3390/ani9070462

23. Chauhan SS, Liu F, Leury BJ, Cottrell JJ, Celi P, Dunshea FR. Functionality and genomics of selenium and vitamin E supplementation in ruminants. Anim Prod Sci. (2016) 56:1285-1298. doi: 10.1071/AN15263

24. Yu LL, Wang RL, Zhang YZ, Kleemann DO, Zhu XP, Jia ZH. Effects of selenium supplementation on polyunsaturated fatty acid concentrations and antioxidant status in plasma and liver of lambs fed linseed oil or sunflower oil diets. Anim Feed Sci Tech. (2008) 140:39-51. doi: 10.1016/j.anifeedsci.2007.02.003

25. Klein HP. Mechanistic Studies of Selenium-Dioxide Oxidations. [dissertation/Ph.D thesis]. [Tucson]; The University of Arizona (1968).

26. Alimohamady R, Aliarabi H, Bahari A, Dezfoulian AH. Influence of different amounts and sources of selenium supplementation on performance, some blood parameters, and nutrient digestibility in lambs. Biol Trace Elem Res. (2013) 154:45-54. doi: 10.1007/s12011-013-9698-4

27. Mickan FJ, Thomas GW, Spiker SA. A comparison between friesian bulls and steers on pasture for lean meat production. Aust J Exp Agr. (1976) 16:297-301. doi: 10.1071/EA9760297

28. Netto AS, Zanetti MA, Claro G, Melo M, Vilela FG, Corr Ea LB. Effects of copper and selenium supplementation on performance and lipid metabolism in confined Brangus bulls. Asian Austral J Anim. (2014) 27:48894. doi: 10.5713/ajas.2013.13400

29. Juszczuk-Kubiak E, Bujko K, Cymer M, Wicińska K, Gabryszuk M, Pierzchała M. Effect of inorganic dietary selenium supplementation on selenoprotein and lipid metabolism gene expression patterns in liver and loin muscle of growing lambs. Biol Trace Elem Res. (2016) 172:33645. doi: 10.1007/s12011-015-0592-0

30. Wheeler TL, Shackelford SD, Johnson LP, Miller MF, Miller RK, Koohmaraie M. A comparison of Warner-Bratzler shear force assessment within and among institutions. J Anim Sci. (1997) 75:2423. doi: 10.2527/1997.7592423x

31. Janani T. Herbs As Antioxidants in Oxidation of Marine Lipids. [dissertation/master's thesis]. [Trondheim]: Norwegian University (2013).

32. Zhang L, Liu Q, Chai Y, Yang F, Cao M, Dai W. In situ growth of g- $\mathrm{C}_{3} \mathrm{~N}_{4}$ on hexangular flowerlike $\mathrm{FeWO}_{4}$ microcrystals: highly efficient catalyst and the crucial roles of $\mathrm{Fe}^{3+} / \mathrm{Fe}^{2+}$ couple in the photoassisted oxidation and reduction reactions. J Phys Chem C. (2018) 122:12900-12. doi: 10.1021/acs.jpcc.8b03575

33. Tian XZ, Xin HL, Paengkoum P, Paengkoum S, Ban C, Sorasak T. Effects of anthocyanin-rich purple corn (Zea mays L.) stover silage on 
nutrient utilization, rumen fermentation, plasma antioxidant capacity, and mammary gland gene expression in dairy goats. J Anim Sci. (2019) 97:138497. doi: 10.1093/jas/sky477

34. Tian XZ, Paengkoum P, Paengkoum S, Chumpawadee S, Ban C, Thongpea S. Short communication: purple corn (Zea mays L.) stover silage with abundant anthocyanins transferring anthocyanin composition to the milk and increasing antioxidant status of lactating dairy goats. J Dairy Sci. (2019) 102:413-8. doi: 10.3168/jds.2018-15423

35. Gardner HW. Oxygen radical chemistry of polyunsaturated fatty acids. Free Radic Biol Med. (1989) 7:65-86. doi: 10.1016/0891-5849(89)90102-0

36. Niki E, Yoshida Y, Saito Y, Nogushi N. Lipid peroxidation: mechanisms, inhibition, and biological effects. Biochem Bioph Res Co. (2005) 338:66876. doi: 10.1016/j.bbrc.2005.08.072

37. Tian XZ, Lu Q, Zhao SG, Li JX, Luo QY, Wang X, et al. Purple corn anthocyanin affects lipid mechanism, flavor compound profiles, and related gene expression of longissimus thoracis et lumborum muscle in goats. Animals. (2021) 11:2407. doi: 10.3390/ani11082407

38. Doreau M, Ferlay A. Digestion and utilisation of fatty acids by ruminants. Anim Feed Sci Tech. (1994) 45:379-96. doi: 10.1016/0377-8401(94)90039-6

39. Purba RAP, Paengkoum P, Paengkoum S. The links between supplementary tannin levels and conjugated linoleic acid (CLA) formation in ruminants: a systematic review and meta-analysis. PLoS ONE. (2020) 15:e0216187. doi: 10.1371/journal.pone.0216187

40. Bialek M, Czauderna M, Przybylski W, Jaworska D. Selenate and selenite affect ruminal metabolism of $\mathrm{C} 18$ unsaturated fatty acids and fatty acid composition of lamb tissues. Livest Sci. (2020) 241:104249. doi: 10.1016/j.livsci.2020.1 04249

41. Kišidayová S, Mihaliková K, Siroka P, Cobanová K, Váradyová Z. Effects of inorganic and organic selenium on the fatty acid composition of rumen contents of sheep and the rumen bacteria and ciliated protozoa. Anim Feed Sci Tech. (2014) 193:51-7. doi: 10.1016/j.anifeedsci.2014.04.008

42. Niedwiedzka KM, Kowalczyk J, Czauderna M. Influence of selenate and linseed oil on fatty-acid and amino-acid profiles in the liver, muscles, fat tissues and blood plasma of sheep. J Anim Feed Sci. (2008) 17:32843. doi: $10.22358 /$ jafs/66612/2008

43. Paengkoum P, Liang JB, Jelan ZA, Baserry M. Utilization of steam-treated oil palm fronds in growing Saanen goats: II supplementation with energy and urea. Asian Austral J Anim. (2006) 19:1623-31. doi: 10.5713/ajas.2006.1623

44. Wanapat M, Chumpawadee S, Paengkoum, P. Utilization of urea-treated rice straw and whole sugar cane crop as roughage sources for dairy cattle during the dry season. Asian Austral J Anim. (2000) 13:4747. doi: 10.5713/ajas.2000.474

45. Ferreira AVDP, Cominotte A, Ladeira MM, Casagrande DR, Teixeira PD, van Cleef E, et al. Feedlot diets with soybean oil, selenium and vitamin E alters rumen metabolism and fatty acids content in steers. Anim Feed Sci Tech. (2020) 260:114362. doi: 10.1016/j.anifeedsci.2019.114362

46. Kaewwongsa W, Traiyakun S, Yuangklang C, Wachirapakorn C, Paengkoum P. Protein enrichment of cassava pulp fermentation by saccharomyces cerevisiae. J Anim Vet Adv. (2011) 10:243440. doi: 10.3923/javaa.2011.2434.2440

47. Paengkoum P. Effects of neem (Azadirachta indica) and leucaena (Leucaena leucocephala) fodders on digestibility, rumen fermentation and nitrogen balance of goats fed corn silage. J Anim Vet Adv. (2010) 9:8836. doi: 10.3923/javaa.2010.883.886

48. Purba R, Yuangklang C, Paengkoum S, Paengkoum P. Milk fatty acid composition, rumen microbial population and animal performance in response to diets rich in linoleic acid supplemented with Piper betle L leaves in saanen goats. Anim Prod Sci. (2020) doi: 10.1071/AN20182

49. Aghwan ZA, Alimon AR, Goh YM, Nakyinsige K, Sazili AQ. Fatty acid profiles of supraspinatus, longissimus lumborum and semitendinosus muscles and serum in Kacang goats supplemented with inorganic selenium and iodine. Asian Austral J Anim. (2014) 27:543-50. doi: 10.5713/ajas.2013. 13545

50. Yong GS, Rathnayake D, Hong SM, Dilawar MA, Yang CJ. Sensory attributes, microbial activity, fatty acid composition and meat quality traits of Hanwoo cattle fed a diet supplemented with stevioside and organic selenium. Foods. (2011) 10:129. doi: 10.3390/foods10010129

51. Pereira ASC, Santos MV, Aferri G, Corte RRPDS, Silva S, Freitas JED Jr, et al. Lipid and selenium sources on fatty acid composition of intramuscular fat and muscle selenium concentration of Nellore steers. Rev Bras Zootecn. (2012) 41:2357-63. doi: 10.1590/S1516-35982012001100009

52. Givens DI, Allison R, Cottrill B, Blake JS. Enhancing selenium content of bovine milk through alteration of the form and concentration of selenium in the diet of dairy cows. J Sci Food Agr. (2004) 84:811-7. doi: 10.1002/jsfa.1737

53. Dumont E, Vanhaecke F, Cornelis R. Selenium speciation from food source to metabolites: a critical review. Anal Bioanal Chem. (2006) 385:130423. doi: 10.1007/s00216-006-0529-8

54. Finaud J, Lac G, Filaire E. Oxidative stress: relationship with exercise and training. Sports Med. (2006) 36:32758. doi: 10.2165/00007256-200636040-00004

55. Dai T, Li J, Lu X, Ye L, Yu H, Zhang L, et al. Prognostic role and potential mechanisms of the ferroptosis-related metabolic gene signature in hepatocellular carcinoma. Pharmacogen Pers Med. (2021) 14:92745. doi: 10.2147/PGPM.S319524

56. Moreno P, Jiménez-Jiménez C, Garrido-Rodríguez M, Calderón-Santiago M, Molina S, Lara-Chica M, et al. Metabolomic profiling of human lung tumor tissues: nucleotide metabolism as a candidate for therapeutic interventions and biomarkers. Mol Oncol. (2018) 12:1778-96. doi: 10.1002/1878-0261.12369

57. Halsted CH. B-vitamin dependent methionine metabolism and alcoholic liver disease. Clin Chem Lab Med. (2013) 51:457-65. doi: 10.1515/cclm-2012-0308

58. Gresakova L, Cobanova K, Faix S. Selenium retention in lambs fed diets supplemented with selenium from inorganic or organic sources. Small Ruminant Res. (2013) 111:76-82. doi: 10.1016/j.smallrumres.2012.10.009

59. Ammerman CB, Miller SM. Selenium in ruminant nutrition: a review. J Dairy Sci. (1975) 58:1561-77. doi: 10.3168/jds.S0022-0302(75)84752-7

60. Fairweather-Tait SJ. Bioavailability of selenium. Eur J Clin Nutr. (1997) 51:S20-3.

61. Radwinska J, Zarczynska K. Effects of mineral deficiency on the health of young ruminants. J Elementol. (2014) 19:91528. doi: 10.5601/jelem.2014.19.2.620

62. Gressley TF. Zinc, copper, manganese, and selenium in dairy cattle rations. In; Proceedings of the 7th Annual Mid-Atlantic Nutrition Conference. College Park: University of Maryland (2009).

63. Kenzo, K. Umami the fifth basic taste: history of studies on receptor mechanisms and role as a food flavor. Biomed Res Int. (2015) 6:189402. doi: 10.1155/2015/189402

64. Zhu Y, Gagaoua M, Mullen AM, Kelly AL, Sweeney T, Cafferky J, et al. A proteomic study for the discovery of beef tenderness biomarkers and prediction of warner-bratzler shear force measured on longissimus thoracis muscles of young Limousin-Sired bulls. Foods. (2021) 10:952. doi: 10.3390/foods 10050952

Conflict of Interest: The authors declare that the research was conducted in the absence of any commercial or financial relationships that could be construed as a potential conflict of interest.

Publisher's Note: All claims expressed in this article are solely those of the authors and do not necessarily represent those of their affiliated organizations, or those of the publisher, the editors and the reviewers. Any product that may be evaluated in this article, or claim that may be made by its manufacturer, is not guaranteed or endorsed by the publisher.

Copyright (c) 2022 Tian, Li, Luo, Wang, Xiao, Zhou, Lu and Chen. This is an open-access article distributed under the terms of the Creative Commons Attribution License (CC BY). The use, distribution or reproduction in other forums is permitted, provided the original author(s) and the copyright owner(s) are credited and that the original publication in this journal is cited, in accordance with accepted academic practice. No use, distribution or reproduction is permitted which does not comply with these terms. 